\title{
Is it Time for Rheumatologists to Readopt Arthroscopy?
}

\author{
Nathan Wei* \\ Arthritis Treatment Center, USA \\ Submission: April 10, 2017; Published: April 13, 2017 \\ *Corresponding author: Nathan Wei, 71 Thomas Johnson Drive Frederick, Maryland 21702, USA.
}

\section{Perspective}

Rheumatology training programs have placed greater emphasis on cognitive talents as opposed to procedural opportunities. Recently, there has been a surge of interest in the use of musculoskeletal ultrasound as an imaging device for both diagnosis as well as treatment with needle guided procedures. While this is a welcome development and improvement over previous rheumatology education, ultrasound is still a black and white two-dimensional tool. Stedman's defines "rheumatology" as "the medical science that deals with the study and treatment of rheumatic diseases". Most rheumatic diseases involve the joints. Therefore it makes sense for rheumatologists to be able to evaluate joint disease as much as possible. While the use of the standard arthroscope is beyond what rheumatology training programs may offer, current technological advances may be better suited for rheumatology (Figure 1).

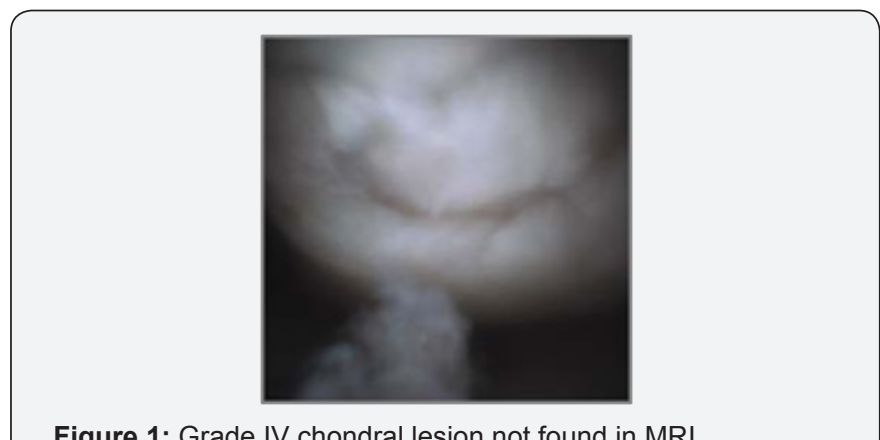

Figure 1: Grade IV chondral lesion not found in MRI.

Most rheumatologists are not aware that arthroscopy, in its early days, was pioneered by rheumatologists like Henri Dorfmann and Thierry Boyer. Unfortunately, this skill was eventually lost and subsequently co-opted by orthopedic surgeons. A unique 14 gauge needle arthroscope with a $120^{\circ}$ field of view (mi-eye 2, Trice Medical, King of Prussia, PA) may now allow rheumatologists to have a 3-dimensional view of their target organ of interest. At our Center, we've been able to evaluate the use of this device both diagnostically as well as therapeutically. The needle arthroscope can be employed with the use of the same antiseptic and anesthetic procedures as a standard arthrocentesis (Figure 2).

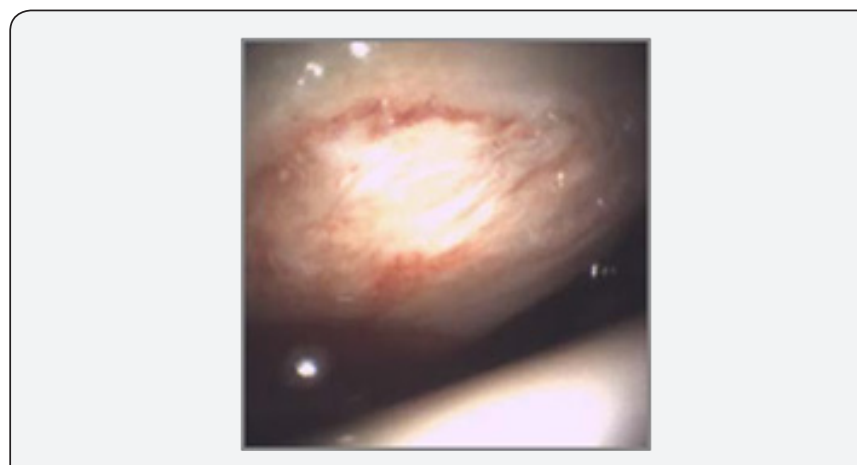

Figure 2: View of the inferior glenoid through mi- eye 2 probe.

Not only has this instrument been helpful as far as evaluating and grading the degree of arthritis but also has allowed us to better determine the cause of a patient's pain. In addition, the needle arthroscope, because of its state-of- the-art design, permits the introduction of therapeutic medication without an additional arthrocentesis. The design and small gauge enables evaluation of multiple joints including the knee, shoulder, wrist, elbow, and ankle (Figure 3). This device probably has the greatest utility when it comes to research efforts. Both observation as well as procurement of tissue is now

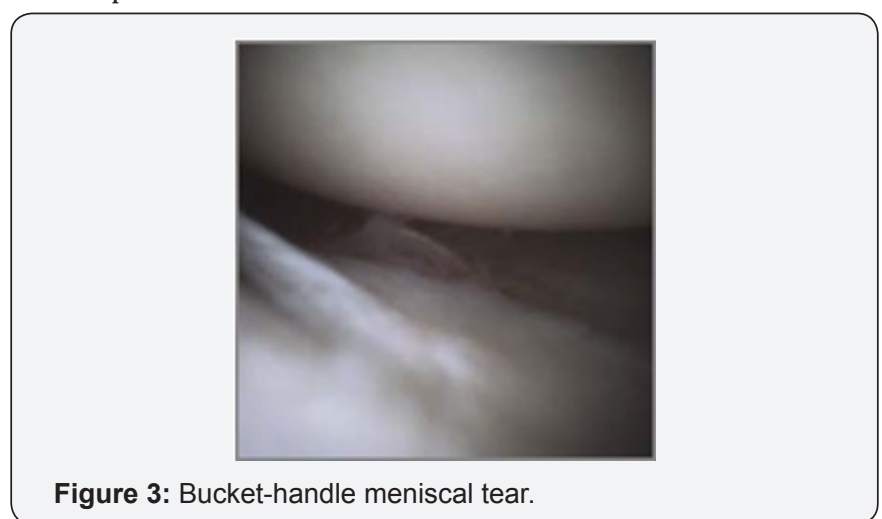

possible with a minimal amount of difficulty, assuming the individual has been trained in the use of the device. That alone should provide the impetus for training programs to adopt this technique. 
This work is licensed under Creative Commons Attribution 4.0 License

DOI: 10.19080/OROAJ.2017.06.555681
Your next submission with Juniper Publishers will reach you the below assets

- Quality Editorial service

- Swift Peer Review

- Reprints availability

- E-prints Service

- Manuscript Podcast for convenient understanding

- Global attainment for your research

- Manuscript accessibility in different formats ( Pdf, E-pub, Full Text, Audio)

- Unceasing customer service

Track the below URL for one-step submission https://juniperpublishers.com/online-submission.php 